\title{
Analysis of Total Laparoscopic Hysterectomy Performed in Our Clinic
}

\author{
Süleyman Salman1, Yavuz Tahsin Ayanoğlu1', Murat Bozkurt², Serkan Kumbasar³, Berker Kavşii, Erkin Sertoğlu1, \\ Refika Genç Koyucu'1 \\ ${ }^{1}$ Clinic of Obstetrics and Gynecology, Gaziosmanpaşa Taksim Training and Research Hospital, İstanbul, Turkey \\ ${ }^{2}$ Department of Obstetrics and Gynecology, Kafkas University Faculty of Medicine, Kars, Turkey \\ ${ }^{3}$ Clinic of Obstetrics and Gynecology, Sakarya Training and Research Hospital, Sakarya, Turkey
}

\section{ABSTRACT}

Objective: The purpose of this study was to evaluate the results of our experience with 83 patients who underwent total laparoscopic hysterectomy (TLH).

Methods: The subjects included 83 patients operated in Gaziosmanpaşa Taksim Training and Research Hospital, Department of Obstetrics and Gynecology. Total laparoscopic hysterectomies were performed for various indications between January 2013 and October 2014 . Indications of total laparoscopic hysterectomy, method of operation, intraoperative and postoperative complications, duration of the operation, length of hospital stay, and blood loss in patients who underwent total laparoscopic hysterectomies were retrospectively evaluated.

Results: In total, 83 patients were included in our study. The mean age was 49.3 years. The most common indication for total laparoscopic hysterectomy was menorrhagia. The mean body mass index (BMI) was $28.7 \pm 4.3$. The mean operation time was $132.16 \pm 48.5$ min, mean hospital stay was $3.38 \pm 1.6$ days, and mean blood loss was $2 \mathrm{~g} / \mathrm{dL}$. The overall complication rate was $6 \%$.

Conclusion: Total laparoscopic hysterectomy is a preferred method to abdominal hysterectomy because it is associated with a more favorable surgical outcome. The laparoscopic approach is an acceptable treatment modality in the current gynecological practice. Total laparoscopic hysterectomy is more beneficial to patients because of low estimated blood loss, less analgesia use, low intraoperative and postoperative complication rates, less postoperative pain, more rapid recovery, and short hospital stays. However, the percentage of total laparoscopic hysterectomies is still very low. The longer operation time in total laparoscopic hysterectomy, an unfavorable learning curve, and extensive training of surgeons and the whole surgical team are often cited as reasons. (JAREM 2015; 5: 10-3)

Keywords: Total laparoscopic hysterectomy, hysterectomy, surgical experience

\section{INTRODUCTION}

Currently, hysterectomy is one of the most common surgical treatments (1). Abdominal, vaginal, and laparoscopic techniques are the surgical techniques used for hysterectomy. Laparoscopic hysterectomy $(\mathrm{LH})$ is more preferable because it offers a more rapid recovery period, less blood loss, lower risk of incisional infection, and earlier discharge from hospital (2). Hysterectomy was first performed vaginally by Recamier in 1829 (3). Abdominal hysterectomy was first performed by Charles Clay in 1843 (4). On the other hand, Harry Reich performed the first LH in 1989 (5). Currently, it is recommended that minimally invasive surgical techniques should be used if hysterectomy is planned for nonmalignant diseases (6). Most hysterectomy procedures are conducted via laparotomy. Abdominal hysterectomy causes more pain and discomfort than vaginal or laparoscopic methods (7). Vaginal hysterectomy is advantageous because it is minimally invasive and provides a more rapid recovery than abdominal hysterectomy. Therefore, vaginal hysterectomy should be the first choice (8). The presence of a large uterus, the presence of an adnexal mass, the absence of uterine prolapses, and previous abdominal surgical operations restrict the application of vaginal hysterectomy (9). LH is performed less frequently, and its three types have been defined. In laparoscopically assisted vaginal hysterectomy (LAVH), although one part of hysterectomy is performed laparoscopically, another part is performed vaginally. In $\mathrm{LAVH}$, the ligation of uterine arteries and the next steps are performed by the vaginal route. In LH, the ligation of uterine arteries is performed laparoscopically, but the next steps are conducted by the vaginal route. On the other hand, in total laparoscopic hysterectomy (TLH), all stages, including the suturing of the vaginal cuff, are performed laparoscopically (10). Although LH has some superiority over abdominal hysterectomy, it has been reported to cause longer operation times, a longer learning curve, and more urinary tract complications (11). Moreover, it has been reported that TLH is more risky in terms of vaginal cuff dehiscence than abdominal and vaginal hysterectomy (12). It has been specified in the guideline of the American Congress of Obstetricians and Gynecologists (ACOG) that LH must be performed to avoid abdominal hysterectomy in the cases in which vaginal hysterectomy cannot be applied or it is contraindicated (13). In this study, the data of 83 patients who underwent TLH in our clinic were examined retrospectively.

\section{METHODS}

The data of 83 patients who underwent a TLH operation at the Gaziosmanpaşa Taksim Training and Research Hospital, Department of Obstetrics and Gynecology between January 2013 and 
October 2014 were investigated. The files of the patients were evaluated retrospectively with respect to age, parity, history of previous surgery, indications of hysterectomy, duration of operation, intraoperative and postoperative complications, estimated blood loss, and length of hospitalization.

Before the operation, pelvic examinations, cervico-vaginal smears, and endometrial samplings were performed. Patients with a malignant disease were excluded from the study. The patients were given liquid food and an oral laxative, and mechanical bowel preparation was performed with a rectal enema on the day before the operation. All patients were administered a prophylactic antibiotic with $1 \mathrm{~g}$ of cefazolin. The duration of the operation was calculated by measuring the time between the first incision on the skin and the last suture on the skin. The difference between preoperative and postoperative hemoglobin $(\mathrm{Hb})$ values was calculated. All operations were performed by the same surgeon, and large vascular injuries, gastrointestinal system injuries, urinary system injuries, a change of the operation to laparotomy, and the need for re-operation due to any reason were accepted as major complications. The patients who had postoperative spontaneous micturition and defecation, were easily mobilized, and did not have an important complaint were discharged from the hospital. All operations were performed under general anesthesia and in the dorsal lithotomy position. All patients had a Foley catheter inserted and a nasogastric tube applied. A manipulator which completely fits over the vaginal fornices was applied in the uterine cavity. The umbilicus was lifted up with clothes pegs, and an approximately $1.5 \mathrm{~cm}$ vertical incision was made in the umbilicus.

Pneumoperitoneum was enabled by entering into the abdomen with a Veress needle. Subsequently, the abdomen was entered with a $10-\mathrm{mm}$ trocar and then with a $10-\mathrm{mm}$ 0-degree telescope. Because the surgeon worked on the left of the patient, the first 5 -mm ipsilaterally lower trocar was inserted approximately $2 \mathrm{~cm}$ medial to the left crista iliaca anterior-posterior and lateral to the inferior epigastric artery. The second $5 \mathrm{~mm}$ trocar was placed in the periumbilical area on the same line, and the third $5 \mathrm{~mm}$ trocar was inserted in the right lower quadrant. Then, the operation was started after the patient was placed in the Trendelenburg position as far as possible. Advanced bipolar electrocoagulation ( $\mathrm{Li}$ gasure, Covidien Company, MA, USA) was used in the operation. As a uterine manipulator, a VCare uterine manipulator (Conmed, NY, USA) was employed. After monitoring the intra-abdominal area and the passageway of the ureter, the round ligament, utero-ovarian, and infundibulopelvic ligament on both sides were cut after being coagulated with Ligasure. After the anterior and posterior leaves of the broad ligament were dissected, the bladder was separated from the cervix by blunt and sharp dissection. Uterine arteries were coagulated and then cut on both sides. After parametrial tissues around the cervix were coagulated with Ligasure and then cut and bleeding areas were coagulated, the entire vaginal wall was circularly separated from the cervix using monopolar L-tipped cautery with the help of a uterine manipulator. The surgical material was removed through the vaginal route. The vaginal cuff was laparoscopically closed with late-absorbable suture materials. Because of the retrospective design of the study, ethics committee approval and patient consent were not obtained.

\section{RESULTS}

The mean age of the patients included in the study was $49.33 \pm 6.53$ years, and the mean parity was $2.4 \pm 3.2(0-8)$. The mean duration of operation was $132.16 \pm 48.5 \mathrm{~min}$, and the mean length of hospitalization was found to be $3.38 \pm 1.6$ (2-10) days. The difference between preoperative and postoperative $\mathrm{Hb}$ was approximately $2 \mathrm{~g} / \mathrm{dL}$. The mean body mass index (BMI) of all patients was $28.7 \pm 4$.3. Fourteen patients $(16.8 \%)$ had a history of previous operation, and 28 patients (33.7\%) were in the period of menopause. The indications for hysterectomy were treatmentresistant menorrhagia in 28 patients (33.7\%), myoma uteri in 23 patients (27.7\%), endometrial hyperplasia in 15 patients (18\%), adnexal mass in 8 patients (9.6\%), adenomyosis in 5 patients (6\%), and cervical intraepithelial neoplasia in 4 patients (4.8\%). The indications for hysterectomy are given in Table 1. Histopathological reports of hysterectomy materials are presented in Table 2. The examination of pathology reports revealed leiomyoma in 28 patients (33.7\%), adenomyosis in 21 patients (25.3\%), endometrial hyperplasia in 19 patients (22.8\%), benign ovarian cyst in 5 patients $(6 \%)$, cervical intraepithelial neoplasia in 4 patients (4.8\%), mucinous cystadenoma in 3 patients (3.6\%), and endometrial polyp in 3 patients (3.6\%). The procedure was switched from laparoscopy to laparotomy in 3 patients because of difficult manipulation and in 2 patients because of uncontrollable bleeding (a total of 5 patients, $6 \%$ ). The mean $\mathrm{Hb}$ values were found to be $10.6 \pm 1.4$ preoperatively and $9.8 \pm 1.7$ postoperatively. The rate of complications was $6 \%$. Vesicovaginal fistula developed in one patient (1.2\%), hemorrhage requiring postoperative transfusion in 2 patients (2.4\%), and spontaneously regressing pelvic hematoma in 2 patients (2.4\%). TLH results are presented in Table 3.

\section{DISCUSSION}

Hysterectomy is the second most common gynecologic surgery after cesarean sections performed by gynecologists. It has a wide range of indications, including dysfunctional uterine bleeding, myoma uteri, gynecologic cancers, uterovaginal prolapse, endometriosis, adenomyosis, pelvic inflammatory disease, and obstetric complications (14). During the years in which LH was first applied, LAVH was the primary method used; however, it was noticed that the amount of bleeding in the uterine artery pedicle was lower in LH than in LAVH (15). Although the advantages and disadvantages of $\mathrm{LH}$ have been defined, it is not commonly implemented because of insufficient technical equipment and a low number of experienced staff (16). Abnormal uterine bleeding and myoma uteri constitute the largest indication group for TLH (17). In our study, the most frequent indications were found to be treatment-resistant menorrhagia and myoma uteri at the rate of $61.4 \%$. If possible, vaginal hysterectomy is the most effective hysterectomy technique, and it has been specified that $\mathrm{LH}$ will not provide an additional benefit for these patients (18). It was reported by Leung et al. (19) that TLH required longer surgery time than $\mathrm{LH}$. In our study, the mean duration of surgery was found to be $132 \mathrm{~min}$. However, we assume that this time will be shorter as our experience increases as a team. It was reported that TLH had a higher rate of complications in addition to longer duration of surgery than other techniques (20). There are different data in the literature about the complications associated with TLH. In a multicenter study including 3643 patients, which was conducted by 
Table 1. Indications for hysterectomy

\begin{tabular}{|l|c|}
\hline Treatment-resistant menorrhagia & $28(33.7 \%)$ \\
\hline Myoma uteri & $23(27.7 \%)$ \\
\hline Endometrial hyperplasia & $15(18 \%)$ \\
\hline Adnexal mass & $8(9.6 \%)$ \\
\hline Adenomyosis & $5(6 \%)$ \\
\hline Cervical intraepithelial neoplasia & $4(4.8 \%)$ \\
\hline
\end{tabular}

Table 2. Histopathological results of hysterectomy materials

\begin{tabular}{|l|c|}
\hline Leiomyoma & $28(33.7 \%)$ \\
\hline Adenomyosis & $21(25.3 \%)$ \\
\hline Endometrial hyperplasia & $19(22.8 \%)$ \\
\hline Benign ovarian cyst & $5(6 \%)$ \\
\hline Cervical intraepithelial neoplasia (CIN3) & $4(4.8 \%)$ \\
\hline Endometrial polyp & $3(3.6 \%)$ \\
\hline Mucinous cystadenoma & $3(3.6 \%)$ \\
\hline
\end{tabular}

Table 3. Total laparoscopic hysterectomy results

\begin{tabular}{|l|c|}
\hline Duration of operation (min) & $132.16 \pm 48.5(40-240)$ \\
\hline Length of hospitalization (days) & $3.38 \pm 1.6(2-10)$ \\
\hline $\begin{array}{l}\text { Switching from laparoscopy to laparotomy } \\
\text { Blood loss (pre- and postoperative } \\
\text { hemoglobin difference) }\end{array}$ & $5(6 \%)$ \\
\hline Vesicovaginal fistula & $2 \mathrm{~g} / \mathrm{dL}$ \\
\hline Hemorrhage & $1(1.2 \%)$ \\
\hline Pelvic hematoma & $2(2.4 \%)$ \\
\hline $\begin{array}{l}\text { Switching from laparoscopic approach to } \\
\text { open surgery }\end{array}$ & $2(2.4 \%)$ \\
\hline Rate of complication & $5(6 \%)$ \\
\hline
\end{tabular}

Johnson et al. (21), it was reported that vaginal and laparoscopic hysterectomies were more advantageous than abdominal hysterectomy, and patients recovered more rapidly, but bladder and ureter injuries were observed more frequently in patients who underwent LH. In the study of Makinen et al. (22) conducted with 2434 patients, the rate of complications was found to be $19 \%$ in patients to whom LH was applied. Malik et al. (23) observed 11 urinary complications in their study including 106 patients. In our study, vesicovaginal fistula was seen in one patient and, in the next operation on this patient, it was observed that bladder injury developed because of suture. In the study of Nezhat et al. (24) with 361 patients, vascular complication was reported in 5 patients (1.39\%). In our study, vascular complication was observed in 2 patients (2.4\%). Shen et al. (25) conducted a study with 284 patients, and they observed intestinal complication in 6 patients (2.11\%). However, no intestinal complication was encountered in our study. The presence of high complication rates is the main reason for avoiding $\mathrm{LH}$. The largest part of these complications consist of urinary system complications, the reason for which was attributed to the application of LH by inexperienced surgeons (26). In the literature, the rate of complications related to the ureter after TLH was reported as $0.5-1 \%$ (27). No ureter-related complication was observed in our study. According to the study of $\mathrm{Ng}$ et al. (28), dissection of the ureter during laparoscopy decreases the possible risk of iatrogenic ureteral injury. In our study, ureteral dissection was performed only on 3 patients because the location of the ureter could not be exactly determined. Excessive use of electrosurgery during TLH can increase urinary tract injury (16). In the evaluation of the length of hospitalization, the length of hospitalization was found to be significantly shorter in TLH than in abdominal hysterectomy, but no significant difference was found compared with vaginal hysterectomy. The mean hospitalization time in TLH was reported to vary between 1.4 and 4 days (27). In our study, the mean hospitalization time was found to be $3.38 \pm 1.6$ days

\section{CONCLUSION}

Total LH is a more preferable hysterectomy technique than abdominal hysterectomy for patients who cannot undergo vaginal hysterectomy. Although the duration of operation is longer than other techniques, it is considered a safe surgical technique that increases patient satisfaction in many aspects when the surgical team reaches an adequate experience level.

Ethics Committee Approval: Ethics committee approval was not received due to the retrospective nature of the study.

Informed Consent: Informed consent was not obtained due to the retrospective nature of the study.

Peer-review: Externally peer-reviewed.

Author contributions: Concept - S.S., Y.T.A.; Design - S.S., S.K.; Supervision - Y.T.A.; Resource - M.B., S.S., B.K., E.S.; Materials - M.B., S.K., R.G.K.; Data Collection and/or Processing - B.K., E.S., R.G.K.; Analysis and/or Interpretation - S.S., Y.T.A.; Literature Search - M.B.; Writing - S.S., B.K., E.S.; Critical Reviews - S.K.; Other - R.G.K.

Conflict of Interest: No conflict of interest was declared by the authors.

Financial Disclosure: The authors declared that this study has received no financial support.

\section{REFERENCES}

1. İsaoğlu Ü, Yılmaz M, Delibaş iB, Gözükara I, Bilici $A E$, Uluğ P, et al. The evaluation of histopathologic diagnosis in specimens of hysterectomy. Abant Med J 2013; 2: 91-4. [CrossRef]

2. Nieboer TE, Johnson N, Lethaby A, Tavender E, Curr E, Garry R, et al. Surgical aproach to hysterectomy for benign gynaecological disease. Cochrane Database of Syst Rev 2009; 8: CD003677. [CrossRef]

3. Cravello L, De Montgolfier R, D'Ercole C, Roger V, Blanc B. Endoscopic surgery. The end of classic surgery? Eur J Obstet Gynecol Reprod Biol 1997; 75: 103-6. [CrossRef]

4. Sutton C. Hysterectomy: a historical perspective. Baillieres Clin Obstet Gynaecol 1997; 11: 1-22. [CrossRef]

5. Reich H, de Caprio J, Mc Glynn F. Laparoscopic hysterectomy. J Gynaecol Surg 1989; 5: 213-6. [CrossRef]

6. AAGL Advancing Minimally Invasive Gynecology Worldwide. AAGL position statement: Route of hysterectomy to treat benign uterine disease. J Minim Invasive Gynecol 2011; 18: 1-3. [CrossRef] 
7. Mahendru R, Malik S, Rana S, Gupta S. Hysterectomy through minilaparotomy for benign gynaecological conditions: A valid option. J Turk Ger Gynecol Assoc 2009; 10: 208-12.

8. Ferrari MM, Berlanda N, Mezzopane R, Raqusa G, Cavallo M, Pardi G. Identifying the indications for laparoscopically assisted vaginal hysterectomy: a prospective, randomised comparison with abdominal hysterectomy in patients with symptomatic uterine fibroids. BJOG 2000; 107: 620-5. [CrossRef]

9. David-Montefiore E, Rouzier R, Chapron C, Darai E. Surgical routes and complications of hysterectomy for benign disorders: a prospective observational study in French university hospitals. Hum Reprod 2007; 22: 260-5. [CrossRef]

10. Reich $\mathrm{H}$, Roberts I. Laparoscopic hysterectomy in current gynaecological practice. Reviews in Gynaecological Practice 2003; 3: 32-40. [CrossRef]

11. Mebes I, Diedrich K, Banz-Jansen C. Total laparoscopic hysterectomy without uterine manipulator at big uterus weight (>280 g). Arch Gynecol Obstet 2012; 286: 131-4. [CrossRef]

12. Hur HC, Guido RS, Mansuria SM, Hacker MR, Sanfilippo JS, Lee TT. Incidence and patient charecteristics of vaginal cuff dehiscence after different modes of hysterectomies. J Minim Invasive Gynecol 2007; 14: 311-7. [CrossRef]

13. Choosing the route of hysterectomy for benign disease. ACOG Committee Opinion No. 444. American Colege of Obstetricians and Gynecologists. Obstet Gynecol 2009; 114: 1156-8. [CrossRef]

14. Davies A, Magos AL. Indications and alternatives to hysterectomy. Baillieres Clin Obstet Gynaecol 1997; 11: 61-75. [CrossRef]

15. Gol M, Kizilyar A, Eminoglu M. Laparoscopic hysterectomy with retroperitoneal uterine artery sealing using Ligasuretrade mark: Gazi hospital experience. Arch Gynecol Obstet 2007; 276: 311-4. [CrossRef]

16. Karacan T, Usta AT, Naki MM, Çalık A, Tosun A, Okuyan E. Kliniğimizde yapılan yüz kırk yedi total laparoskopik histerektomi olgusunun analizi. IKSST Derg 2014; 6: 6-13. [CrossRef]

17. Terzi H, Kale A, Aydın AY. Kliniğimizde gerçekleştirilen laparoskopik histerektomi olgularının klinik özelliklerinin değerlendirilmesi. Kocaeli Tıp Dergisi 2012; 2: 22-5.
18. Ottosen $C$, Lingman G, Ottosen L. Three methods for hysterectomy: a randomised, prospective study of short term outcome. BJOG 2000; 107: 1380-5. [CrossRef]

19. Leung SW, Chan SC, Lo SF, Pang CP, Pun TC, Yuen PM. Comparison of the different types of laparoscopic total hysterectomy. J Minim Invasive Gynecol 2007; 12: 91-6. [CrossRef]

20. Donnez O, Jadoul P, Squifflet J, Donnez J. A series of 3190 laparoscopic hysterectomies for benign disease from 1990 to 2006: evaluation of complications compared with vaginal and abdominal procedures. BJOG 2009; 116: 492-500. [CrossRef]

21. Johnson N, Barlow D, Lethaby A, Tavender E, Curr L, Garry R. Methods of hysterectomy: systematic review and meta-analysis of randomised controlled trials. BMJ 2005; 330: 1478. [CrossRef]

22. Mäkinen J, Johansson J, Tomas C, Tomas E, Heinonen PK, Laatikainen T, et al. Morbidity of 10110 hysterectomies by type of approach. Hum Reprod 2001; 16: 1473-8. [CrossRef]

23. Malik E, Schmidt M, Scheidel P. Complications after 106 laparoscopic hysterectomies. Zentrabl Gynakol 1997; 119: 611-5.

24. Nezhat F, Nezhat $C H$, Adman D, Gordon S, Nezhat C. Complications and results of 361 hysterectomies performed at laparoscopy. J Am Coll Surg 1995 ;180: 307-16.

25. Shen CC, Lu HM, Chang SY. Characteristics and management of large bowel injury in laparoscopic assisted vaginal hysterectomy. J Am Assoc Gynecol Laparosc 2009; 9: 35-9. [CrossRef]

26. Donnez O, Donnez J. A series of 400 laparoscopic hysterectomies for benign disease: a single centre, single surgeon prospective study of complications confirming previous retrospective study. BJOG 2010; 117: 752-5. [CrossRef]

27. Garry R, Fountain J, Mason S, Hawe J, Napp V, Abbott J, et al. The evaluate study: two parallel randomised trials, one comparing laparoscopic with abdominal hysterectomy, the other comparing laparoscopic with vaginal hysterectomy. BMJ 2004; 328: 129. [CrossRef]

28. Ng CC, Chern BS. Total laparoscopic hysterectomy: a 5- year experience. Arch Gynecol Obstet 2007; 276: 613-8. [CrossRef] 